Review began 02/24/2022 Review ended 02/27/2022 Published 02/27/2022

(c) Copyright 2022

Maurya et al. This is an open access article distributed under the terms of the Creative Commons Attribution License CC-BY 4.0. which permits unrestricted use, distribution, and reproduction in any medium, provided the original author and source are credited.

\title{
Various Options for Scrotal Reconstruction: A Prospective Observational Study
}

\author{
Rajesh Maurya ${ }^{1}$, Mohd Altaf Mir ${ }^{1}$, Sumeet Mahajan ${ }^{1}$ \\ 1. Burns \& Plastic Surgery, All India Institute of Medical Sciences, Bathinda, IND \\ Corresponding author: Mohd Altaf Mir, draltafmir@gmail.com
}

\section{Abstract}

\section{Background}

Scrotal defects in developing countries are common challenges for the reconstructive surgeon and hence this work has been done with the aim to compare the outcome, advantages and disadvantages of different modalities of scrotal reconstruction.

\section{Methods}

The prospective observational hospital-based study of reconstruction of scrotal defects following trauma and Fournier's gangrene was done over a period of three years. Scrotal defect reconstruction was done in 35 patients by scrotal advancement flap, split thickness skin grafting, medial thigh flap, anterolateral thigh flap and groin flap keeping in mind the various indication of different modalities. The reconstructed scrotums were observed for flap survival and skin graft intake for seven to 10 days in the hospital and then were followed for three months in a follow-up clinic.

\section{Results and observations}

The mean age of our patients was $48.57 \pm 5.01$ years. Most of the soft tissue defects of the scrotum were posttraumatic (83\%). Scrotal reconstruction was done often by flaps and more frequently used flap for reconstruction of scrotum was scrotal advancement flap. All flaps and grafts survived well. Mean hospitalization time was highest for groin flap cover whereas mean operative time was highest for anterolateral thigh flap cover.

\section{Conclusion}

Every case of scrotal defect needs an individual approach for scrotal reconstruction depending upon patient age, general condition of the patient, wound status, and the patient's requirement.

Categories: Plastic Surgery, Urology, General Surgery

Keywords: psychosexual, flap, grafting, gangrene, trauma, scrotum

\section{Introduction}

Trauma and Fournier's gangrene can cause significant soft tissue loss involving the scrotum, penis and thighs. The soft tissue coverage of scrotal defects and exposed testes is vital for the protection of testicular function and sparing the sexual wellbeing of the person. Reconstruction is also important for perineal cosmesis and the psychological wellbeing of a patient. Various reconstructive procedures are split thickness skin grafting and flaps.

Trauma is the leading cause of soft tissue loss of the scrotum worldwide, however in developing countries Fournier's gangrene is still contributing to a significant proportion of soft tissue loss of the scrotum.

Fournier's gangrene is a rapidly progressive, fatal, necrotizing fasciitis involving skin and soft tissue of the scrotum and perineum. Several terms that have been used alternatively for Fournier's gangrene are streptococcus gangrene, necrotizing fasciitis, periurethral phlegmon, phagedaena and synergistic necrotizing fasciitis [1].

Systemic conditions such as alcoholism, diabetes mellitus, paralysis or neurological deficit and immunosuppression are predisposing factors of Fournier's gangrene [2]. Men are most commonly involved and it can present in any age group. Fournier's gangrene may occur in children following insect bite and trauma [3].

It can cause significant soft tissue loss involving the scrotum, penis and thighs. Since the testes have an independent vascular supply, they survive but may have secondary function loss. After debridement and control of infection, skin coverage of scrotal defects and exposed testes is indispensable. 


\section{Cureus}

Reconstruction of the scrotum is important for functional, cosmetic and psychological wellbeing [4]. Various techniques that have been described for the reconstruction of these defects are split thickness skin grafts (STSG) [5], muscle flaps [6], fascio-cutaneous flaps [7], perineal flap [8], anterolateral thigh flap (ALT) [4], deep inferior epigastric perforator flap [9] and anteromedial thigh flap (AMT) [10].

Scrotal defects in developing countries are a common challenge to the reconstructive surgeon and hence this work has been done with the aim to compare the outcome, advantages and disadvantages of different modalities of scrotal reconstruction.

\section{Materials And Methods}

\section{Study design}

The prospective observational hospital-based study of reconstruction of scrotal defects following trauma and Fournier's gangrene was done over a period of three years. The study was conducted at the first two author's previous institution after institutional ethical approval and is registered vide reference number $642 / \mathrm{FM} / 17$

\section{Study population and sample size}

Patients with soft tissue defects of the scrotum following trauma $(n=29)$ and Fournier's gangrene $(n=6)$ who underwent reconstruction were included in the study and observed prospectively during the hospitalized period and then afterward for three months. The sample size calculation was performed using OpenEpi (OpenEpi, Version 3, open-source calculator-SS Cohort) online tool. Considering $80 \%$ power with $5 \%$ of significance and high effect size, the sample size calculated was 35 . The study design and population are described in Figure 1. 


\section{Cureus}

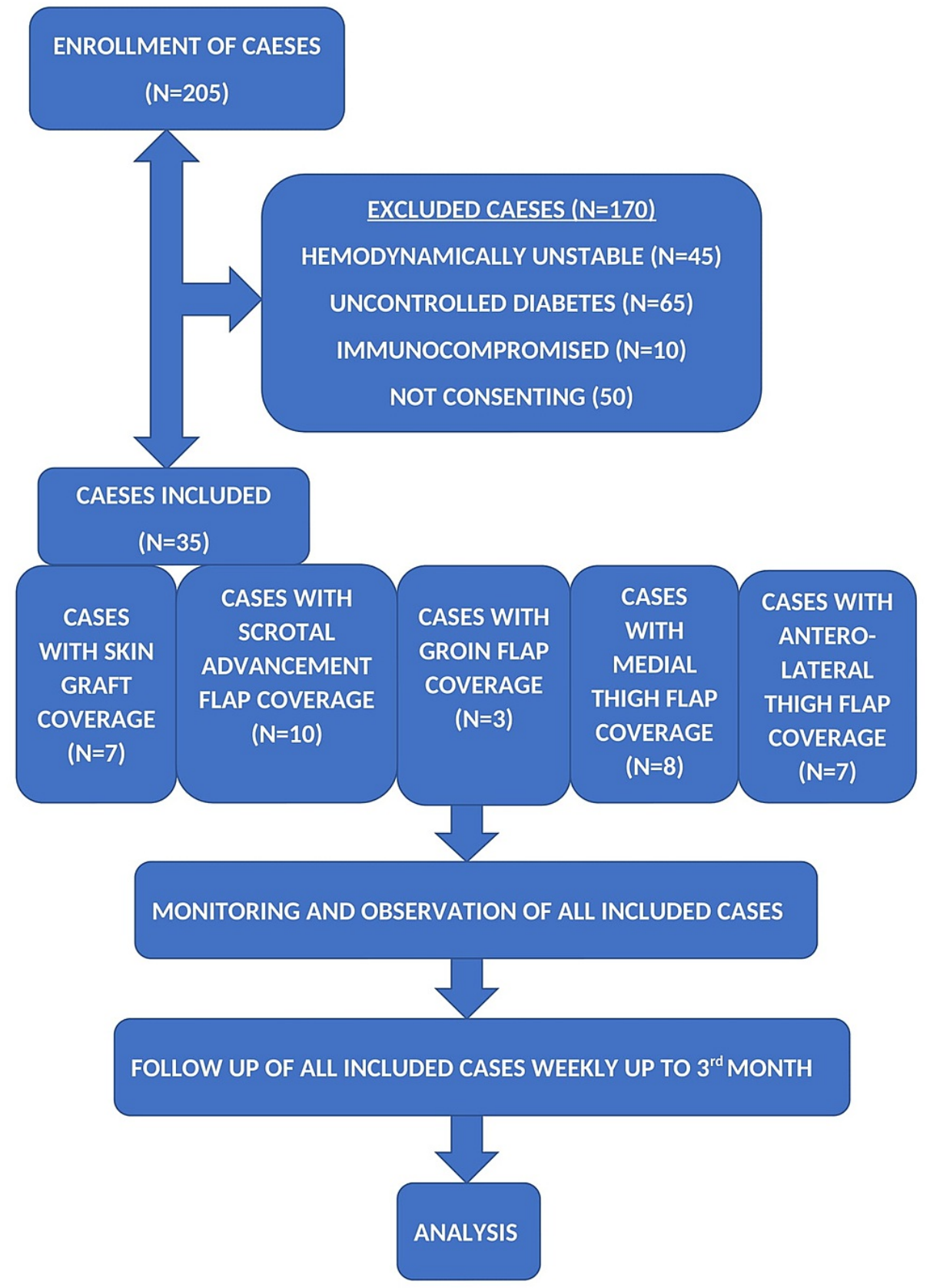

\section{FIGURE 1: Study design}

Flow diagram depicting the number of cases recruited, excluded and included. It also show the number of cases in each mode of management and the overall study design from recruitment of cases to end of follow up.

\section{Selection criteria for study participants}

All patients from 16-59 years of age with scrotal soft tissue defects who underwent tissue coverage were included in the study. Children of less than 16 years and elderly of more than 59 years, hemodynamically unstable patients, immunocompromised patients, uncontrolled diabetes and critically ill patients not fit for anesthesia were excluded.

The scrotal defect coverage was done by various method chosen according to size of defect, age and comorbidities of the patient. In our study scrotal defect reconstruction was done in 35 patients with scrotal advancement flap, split thickness skin grafting, medial thigh flap , anterolateral thigh flap and groin flap, keeping in mind various indications for different modalities. Patients were observed for seven to 10 days in ward for skin graft take clinically and flap viability clinically and using hand held vascular doppler. After discharge from hospital the patients were followed weekly in a follow-up clinic for three months addressing size of scrotum, color and hair bearing skin of scrotum, scar appearance at scrotum and donor site 


\section{Cureus}

morbidity.

The aesthetic outcome of operated patients was evaluated at two months of follow-up through Likert scale based on a questionnaire that included assessment of size of scrotum, shape and appearance, scrotum color and donor site scar by three independent plastic surgeons. The satisfaction score was calculated as per Table

\begin{tabular}{|c|c|c|c|c|}
\hline Criteria & Very unsatisfied & Unsatisfied & Satisfied & Very satisfied \\
\hline Size of scrotum & 1 & 2 & 3 & 4 \\
\hline Shape and appearance of scrotum & 1 & 2 & 3 & 4 \\
\hline Color & 1 & 2 & 3 & 4 \\
\hline Donor site scar & 1 & 2 & 3 & 4 \\
\hline
\end{tabular}

\section{TABLE 1: Likert scale of satisfaction after scrotal reconstruction.}

The parameters for satisfaction score used for aesthetic assessment after reconstruction by three independent Plastic Surgeons.

\section{Data collection and statistical analysis}

The data was recorded as per set Performa which was then tabulated in a Microsoft Excel spread sheet. The data has been analyzed using Statistical Package for Social Sciences (SPSS) version 26.0 (IBM Corp., Armonk, NY, USA). The results are expressed as mean \pm standard deviation (SD) for discrete data and proportions for descriptive data.

\section{Results}

The mean age of our patients was $48.57 \pm 5.01$ years. Most of the soft tissue defects of the scrotum were posttraumatic (83\%) and Fournier's gangrene contributed to $17 \%$. The soft tissue defects after Fournier's gangrene often required wound optimization before tissue coverage. The scrotal defect coverage was done with various methods chosen according to size of defect and age and comorbidities of patient. In our study scrotal defect reconstruction was done in 35 patients by scrotal advancement flap, split thickness skin grafting (Figure 2), medial thigh flap (Figure 3), anterolateral thigh flap (Figure 4) and groin flap (Figure 5) keeping in mind various indications for different modalities. 


\section{Cureus}
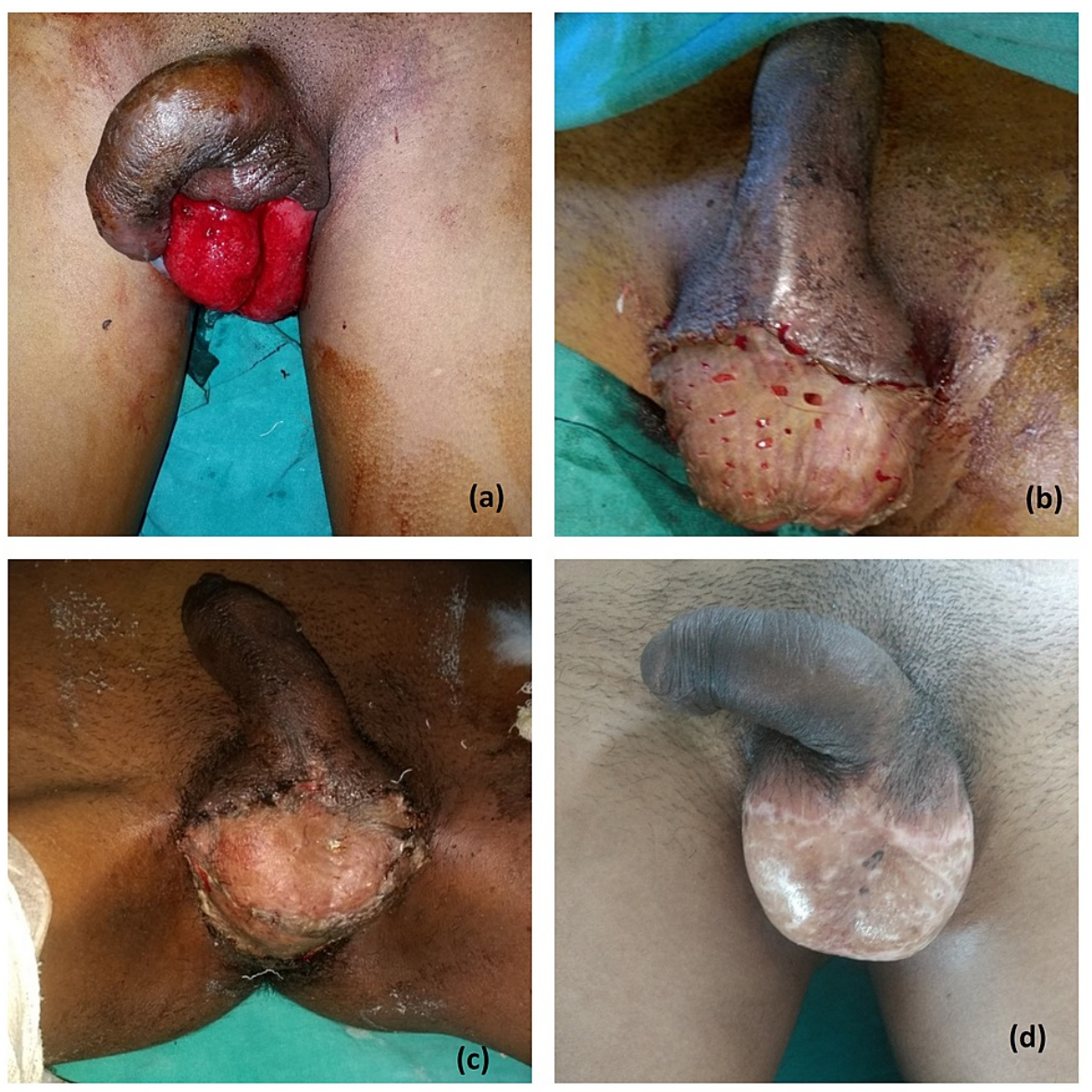

FIGURE 2: Split thickness skin grafting (STSG).

Management of soft tissue defects of the scrotum with STSG. Panel a shows scrotal soft tissue defect, panel $b$ shows STSG cover, panel $\mathrm{c}$ is a post-operative image suggesting satisfactory graft uptake and panel d depicts final results at three months follow-up. 


\section{Cureus}
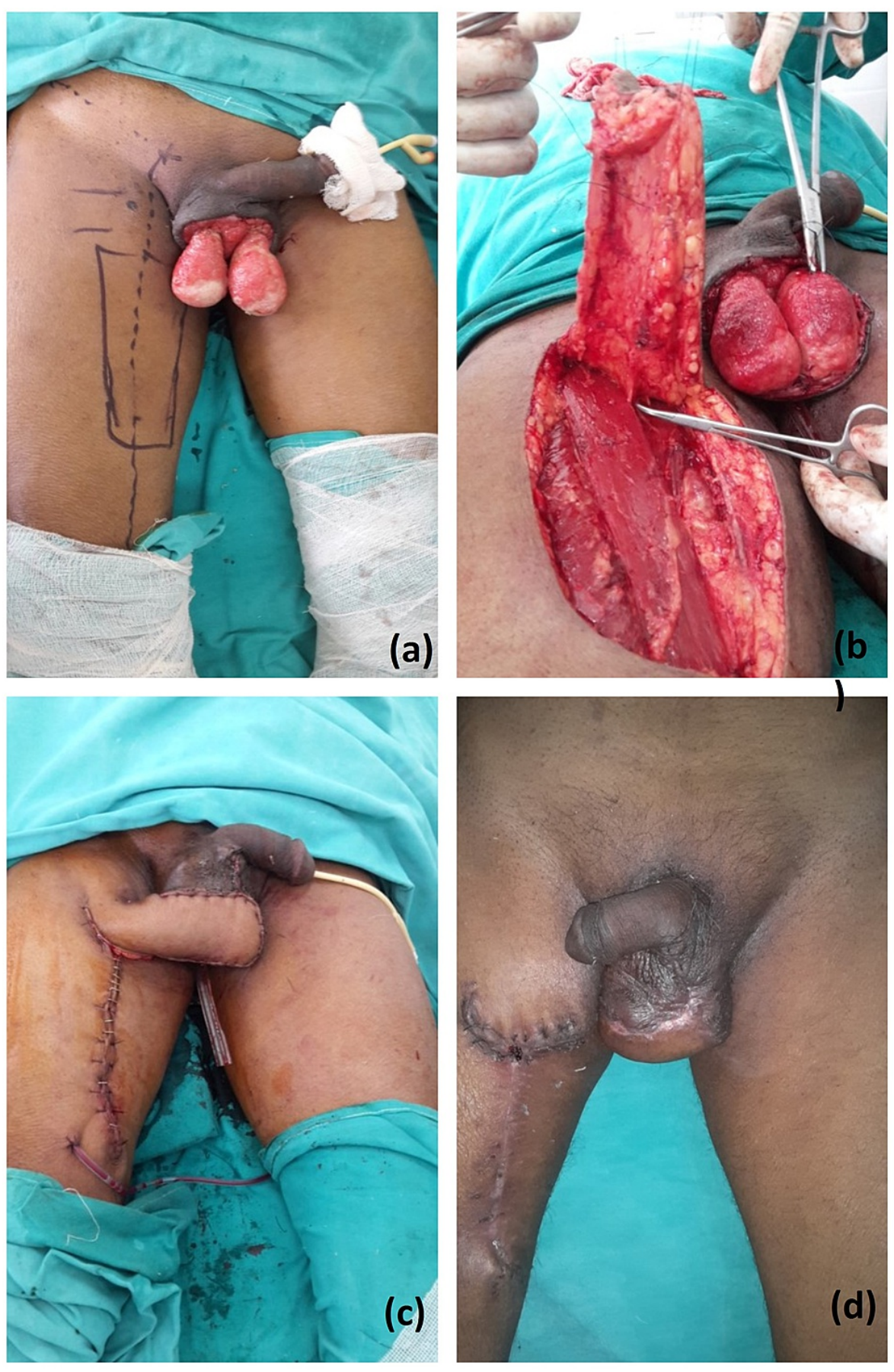

FIGURE 3: Medial thigh flap coverage.

Panel a depicts a soft tissue scrotal defect and medial thigh flap marking, panel $b$ shows raised medial thigh flap and supplying perforator, panel c shows immediate flap coverage of the scrotal defect and panel $d$ is a follow-up photograph at two weeks suggesting healthy flap. 


\section{Cureus}
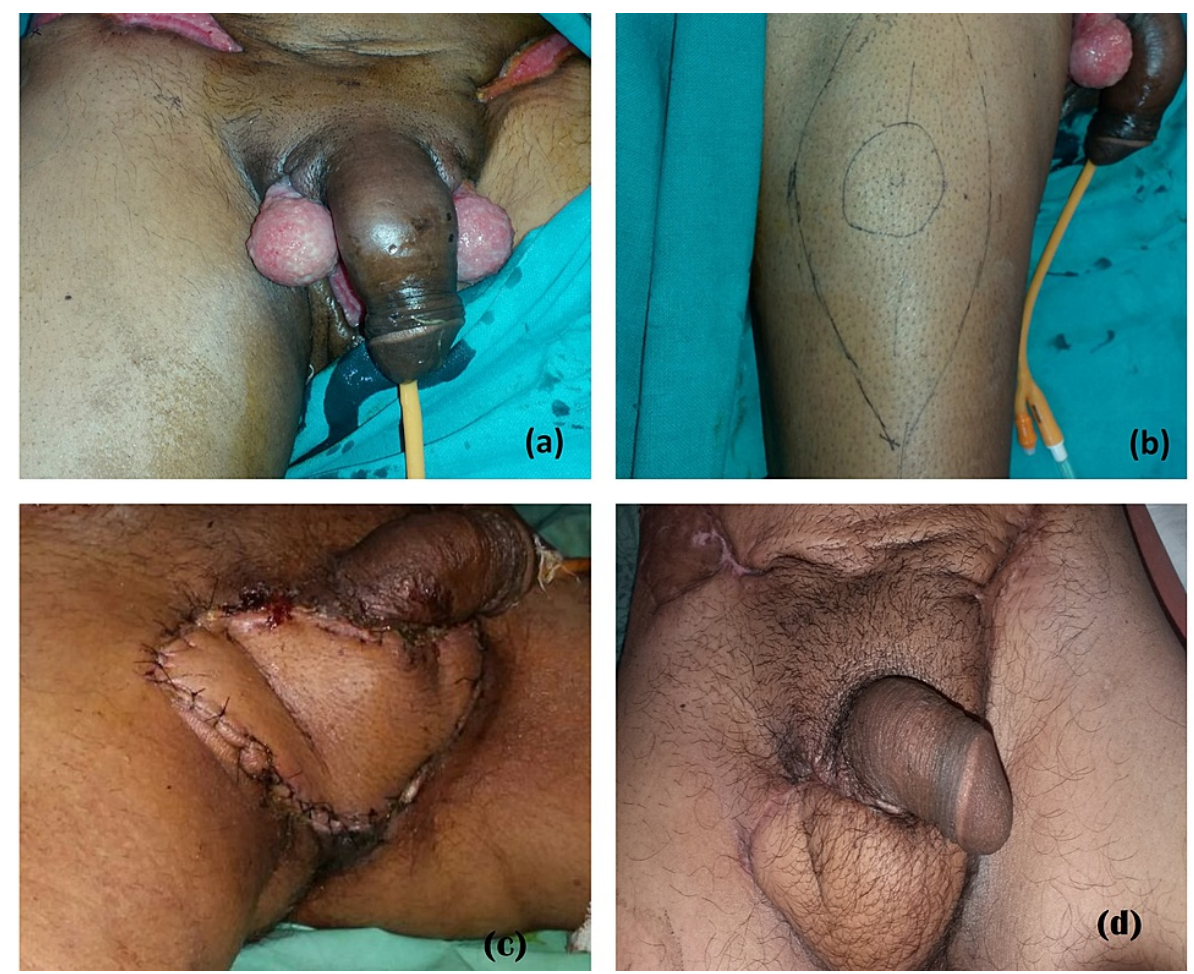

FIGURE 4: Anterolateral thigh (ALT) flap coverage.

Panel a depicts a soft tissue scrotal defect with exposed testicles, panel b shows ALT flap marking, panel c shows flap coverage of the defect and panel $d$ shows healed flap at three months follow-up. 


\section{Cureus}
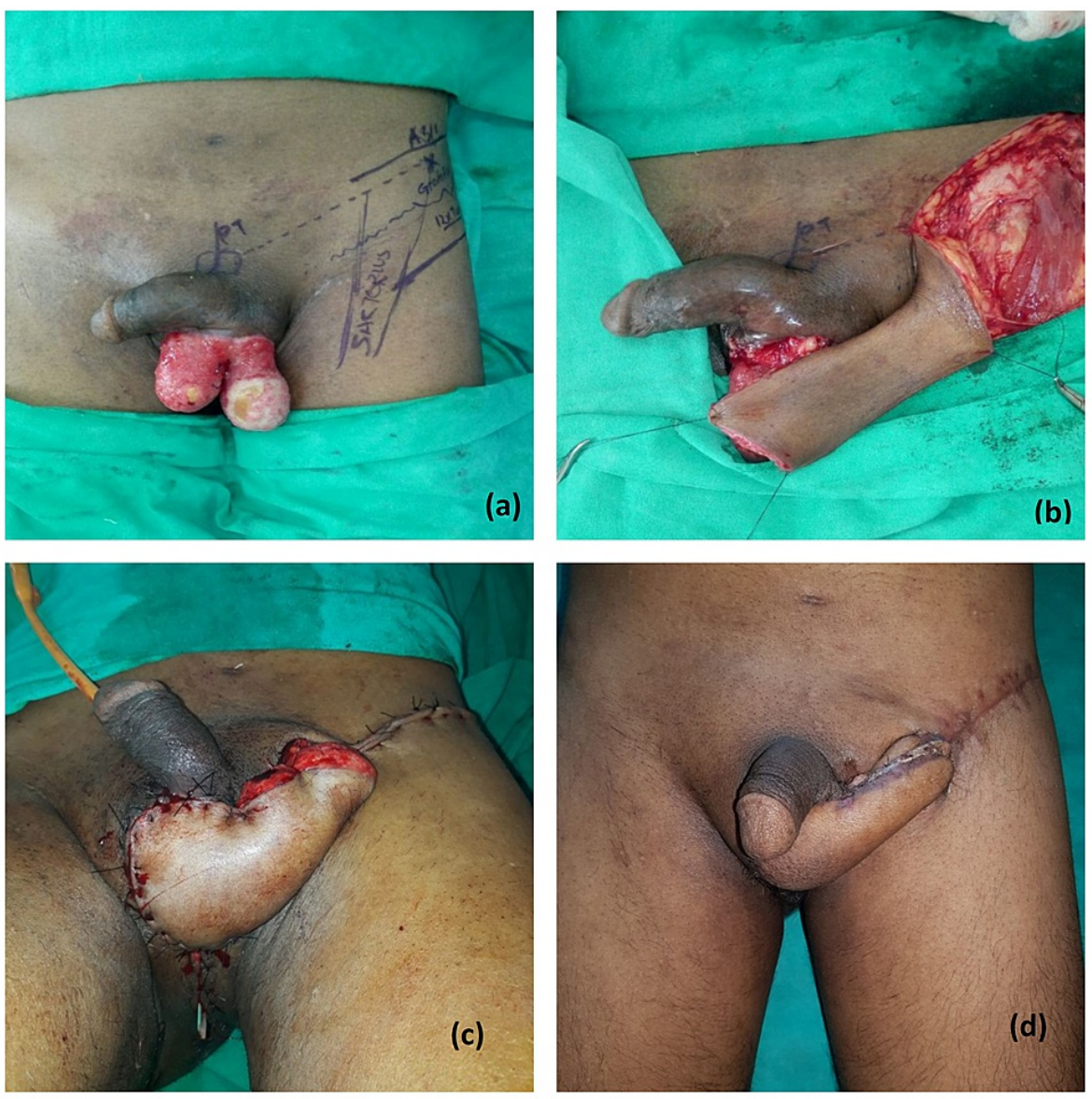

\section{FIGURE 5: Groin flap coverage.}

Panel a shows soft tissue defect of scrotum with exposed testicles, panel b shows raised groin flap and arch of rotation of the flap, panel $\mathrm{c}$ depicts immediate flap coverage of the scrotal defect and panel $\mathrm{d}$ suggests healthy flap at two months follow-up.

The scrotal reconstruction was done often by flaps and the most frequently used flap for reconstruction of the scrotum was scrotal advancement flap. All flaps and grafts survived well. Mean hospitalization time was highest for groin flap cover whereas mean operative time was highest for anterolateral thigh flap cover. Various complications seen in patients treated with different reconstructive techniques are mentioned in Table 2. 


\section{Cureus}

\begin{tabular}{|c|c|c|c|c|}
\hline Procedure & $\begin{array}{l}\text { Total number of } \\
\text { patients }(n=35)\end{array}$ & $\begin{array}{l}\text { Mean Hospitalization time } \pm \\
\text { SD (in days) }\end{array}$ & $\begin{array}{l}\text { Mean operative time } \pm \text { SD } \\
\text { (in minutes) }\end{array}$ & Complications \\
\hline $\begin{array}{l}\text { Scrotal } \\
\text { advancement flap }\end{array}$ & $10(28.57 \%)$ & $8.7 \pm 2$ & $50 \pm 4.5$ & Nil \\
\hline $\begin{array}{l}\text { Split thickness skin } \\
\text { grafting }\end{array}$ & $7(20 \%)$ & $9.4 \pm 2.3$ & $60 \pm 4.6$ & $\begin{array}{l}\text {-Infection at recipient site } \\
(n=1) \\
\text {-Perineo-scrotal gap }(n=1)\end{array}$ \\
\hline \multirow{5}{*}{$\begin{array}{l}\text { Medial thigh flap } \\
\text { cover }\end{array}$} & \multirow{5}{*}{$8(22.86 \%)$} & \multirow{5}{*}{15.8} & \multirow{5}{*}{$120 \pm 29.9$} & $\begin{array}{l}\text {-Partial distal necrosis of } \\
\text { flap }(n=2)\end{array}$ \\
\hline & & & & $\begin{array}{l}\text {-Un-recovered sensation } \\
(n=1)\end{array}$ \\
\hline & & & & -Bulky flap $(n=1)$ \\
\hline & & & & -Wound dehiscence $(n=1)$ \\
\hline & & & & $\begin{array}{l}- \text {-lnfection of suture line } \\
(n=1)\end{array}$ \\
\hline \multirow{3}{*}{$\begin{array}{l}\text { Anterolateral thigh } \\
\text { flap cover }\end{array}$} & \multirow{3}{*}{$7(20 \%)$} & \multirow{3}{*}{16.1} & \multirow{3}{*}{$150 \pm 32.9$} & $\begin{array}{l}\text {-Marginal flap necrosis } \\
(n=2)\end{array}$ \\
\hline & & & & -Bulky flap (n=3) \\
\hline & & & & $\begin{array}{l}\text {-Wound dehiscence and } \\
\text { infection }(n=2)\end{array}$ \\
\hline Groin flap cover & $3(8.57 \%)$ & 18 & $105 \pm 24.4$ & Nil \\
\hline
\end{tabular}

\section{TABLE 2: Various reconstructive techniques and their outcomes.}

(n) -Number in brackets in complications indicates the number of patients.

The aesthetic outcomes were evaluated through Likert scale based on a questionnaire that included assessment of the size of the scrotum, shape and appearance, scrotum color and donor site scar by three independent plastic surgeons. The aesthetic outcome was highly satisfactory after scrotal advancement flaps with mean \pm SD score of $11.5 \pm 1.61$ followed by anterolateral thigh flap $11.4 \pm 1.98$ and least after skin grafting $9.7 \pm 1.99$. A summary of aesthetic results is given in Table 3 .

\begin{tabular}{|c|c|c|}
\hline Procedure & Number of patients & Mean Satisfaction score \pm SD \\
\hline Scrotal advancement flap & 10 & $11.5 \pm 1.61$ \\
\hline Split thickness skin grafting & 7 & $9.7 \pm 1.99$ \\
\hline Medial thigh flap cover & 8 & $11.3 \pm 2.01$ \\
\hline Anterolateral thigh flap cover & 7 & $11.7 \pm 1.98$ \\
\hline Groin flap cover & 3 & $10.3 \pm 1.87$ \\
\hline
\end{tabular}

TABLE 3: Summary of aesthetic results.

The table shows aesthetic outcome was highly satisfactory after scrotal advancement flaps followed by anterolateral thigh flap and least after skin grafting

After the completion of our study, we were able to derive the following advantages and disadvantages of various modalities of scrotal reconstruction, which are tabulated below in Table 4 . Consideration of the listed advantages and disadvantages of these different flaps and STSG in Table 4 can help in decision making of the type of flap required in different cases of scrotal soft tissue defects in different clinical scenarios. Table 4 describes the advantages and disadvantages in detail. 


\section{Cureus}

\begin{tabular}{|c|c|c|}
\hline $\begin{array}{l}\text { Name of } \\
\text { procedure }\end{array}$ & Advantages & Disadvantages \\
\hline \multirow{6}{*}{$\begin{array}{l}\text { Delayed } \\
\text { primary } \\
\text { closure }\end{array}$} & Follow the principle of replace like with like & For small defect only \\
\hline & $\begin{array}{l}\text { Reconstruction by undermining and } \\
\text { advancement }\end{array}$ & $\begin{array}{l}\text { Extensive undermining may cause scrotal flap loss or wound edge } \\
\text { necrosis }\end{array}$ \\
\hline & Simple, safe and easy procedure & - \\
\hline & Less recovery time & - \\
\hline & Shorter hospital stays & - \\
\hline & Acceptable cosmetic appearance & - \\
\hline \multirow{7}{*}{$\begin{array}{l}\text { Split } \\
\text { thickness } \\
\text { skin grafting }\end{array}$} & contour well to irregular surface & Sensitive and prone to mechanical trauma \\
\hline & $\begin{array}{l}\text { Can be used in conjunction with local flap } \\
\text { coverage }\end{array}$ & Scar contracture may be seen \\
\hline & Simple, safe, easy and one stage procedure & $\begin{array}{l}\text { Appearance in not completely natural since the new sac lacks } \\
\text { redundant skin and testicles are not freely floating, instead testes } \\
\text { remain in a low position due to loss of cremasteric function. }\end{array}$ \\
\hline & $\begin{array}{l}\text { Thin skin resembles normal scrotal skin, contour } \\
\text { and shape }\end{array}$ & $\begin{array}{l}\text { Pain, discomfort due to lack of mobility between grafted skin and testes } \\
\text { also reported }\end{array}$ \\
\hline & $\begin{array}{l}\text { The testicular function is preserved because } \\
\text { testis remains cool (testicle temperature low and } \\
\text { may add spermatogenesis) }\end{array}$ & $\begin{array}{l}\text { STSG cannot be performed if testes have been stripped of tunica } \\
\text { vaginalis }\end{array}$ \\
\hline & Decreased recovery time & - \\
\hline & Shorter hospital stays & - \\
\hline \multirow{8}{*}{$\begin{array}{l}\text { Medial thigh } \\
\text { flap cover }\end{array}$} & technically simple & Sometimes mild oedema of lower limbs \\
\hline & Advance easily to defects & Paresthesia of anterior surface of thigh \\
\hline & Minimal disruption to donor sites & bulkiness of flap \\
\hline & Single stage & $\begin{array}{l}\text { impaired spermatogenesis as a result of difficulty in maintaining lower } \\
\text { temperature in the testicle }\left(35^{\circ} \mathrm{C}\right)\end{array}$ \\
\hline & Sensate flaps & - \\
\hline & donor site closed primarily & - \\
\hline & Functional expandability & - \\
\hline & $\begin{array}{l}\text { Achieve reasonable aesthetic result. Very } \\
\text { vascular and safe to use, even in diabetic and } \\
\text { vasculopathy patients }\end{array}$ & - \\
\hline \multirow{6}{*}{$\begin{array}{l}\text { Anterolateral } \\
\text { thigh flap } \\
\text { cover }\end{array}$} & Sensate and large flaps & More difficult dissection with vascular anatomy variability \\
\hline & The flap is out of zone of infection & $\begin{array}{l}\text { cannot be used in poorly managed diabetic patients because prone to } \\
\text { wound dehiscence and infection }\end{array}$ \\
\hline & Have hair bearing skin & $\begin{array}{l}\text { In obese patients the ALT flap would be thick and hence and unsuitable } \\
\text { for coverage of scrotal defect }\end{array}$ \\
\hline & $\begin{array}{l}\text { Flap looks bulky in initial post operative period } \\
\text { but in the long term the oedema subsides } \\
\text { leaving a natural looking scrotum }\end{array}$ & \\
\hline & $\begin{array}{l}\text { Flap can be harvested as a musculocutaneous } \\
\text { flap with part of vastus lateralis muscle that can } \\
\text { be used to obliterate dead space }\end{array}$ & - \\
\hline & $\begin{array}{l}\text { flap can also be harvested as a neurocutaneous } \\
\text { flap with lateral cutaneous nerve of thigh }\end{array}$ & - \\
\hline
\end{tabular}




\section{Cureus}

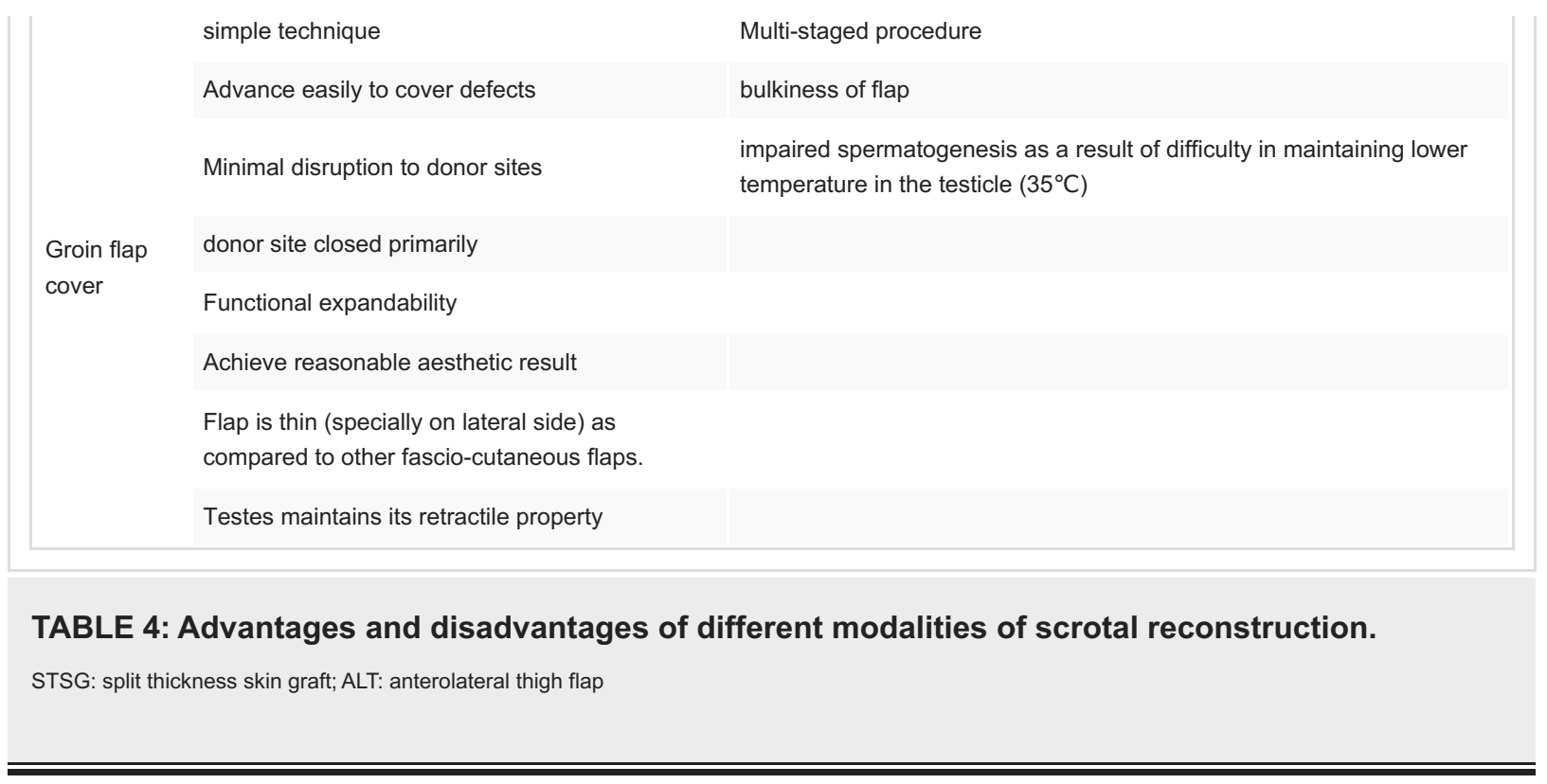

\section{Discussion}

Reconstruction of a scrotal defect poses a challenge after surgical debridement. The "replace like with like" principle has an important role in functional and aesthetic reconstruction of scrotal defects, which is difficult because of its unique texture, color and contour.

According to Chen et al. [10], when the scrotal defect area is less than half the scrotal surface area, scrotal advancement flap can be performed. Closure of scrotal defect with remnant scrotal tissue has an advantage of the testes being covered with native tissue so appearance is similar to the original scrotum. Since testes are covered with native tissue, spermatogenesis is affected minimally, in contrast to fascio-cutaneous flaps. There is no donor site morbidity. The procedure is safe and simple without the risk of any complications besides reducing the hospital stay and hence, cost as well. Chen et al. [11] reported successful scrotal defect reconstruction in 11 patients using the scrotal advancement flap. All patients had scrotal defects less than half the surface area of scrotum. Partial flap loss was seen in one patient and wound edge necrosis was seen in two patients in their study. We have also done scrotal defect resurfacing by scrotal advancement flap in 10 patients having scrotal defect less than $50 \%$ of scrotal surface area and all flaps survived well without any complications.

Balakrishnan was the first to use skin grafts to manage scrotal defects [12]. Split thickness skin grafting is a safe, cost-effective method of scrotal defect reconstruction that is technically easy to perform. The reconstructed scrotum is identical in color and shape to the original scrotum, besides, having thin skin which keeps the testis cooler than the normal body temperature. However, the newly constructed scrotum lacks the redundant skin. Also, testicles keep lying in a low position due to loss of cremasteric function [13]. Hesselfeldt-Nielsen and co-workers had reported three such cases of scrotal defect reconstruction with split thickness skin grafting with excellent results except for the lack of cremasteric suspensory function which was taken care of easily by using ordinary tight underpants [14]. Several authors have reported the use of split thickness skin grafting for scrotal reconstruction following Fournier's gangrene. Parkash and Gajendran reported 43 cases of scrotal reconstruction following Fournier's gangrene [15]. Altcheck and Hoffman [16] managed scrotal defect following Fournier's gangrene using various reconstruction modalities such as split thickness skin grafting, myo-cutaneous flaps and placement of testis in subcutaneous thigh and abdominal wall pockets and concluded that the modality of choice for scrotal reconstruction should be split thickness skin grafting. We have also resurfaced scrotal defects in seven patients with split thickness skin grafting with acceptable aesthetic results.

A number of flaps have been reported in literature for scrotal reconstruction, however these flaps are bulky unlike normal scrotal skin. Besides, excessive fat content of thick fascio-cutaneous flaps can increase the temperature around testes resulting in inhibition of spermatogenesis. Due to complex techniques or multistage operations in some cases, the hospital stay is also prolonged adding to the monetary burden of patient. The only absolute indication for flap reconstruction is when vital structures such as the tunica, corpora and urethra are breached. Flaps, however, provide hair-bearing skin and more durable soft tissue than skin graft which is the chief advantage of using flaps for scrotal reconstruction. Flap coverage has reliable vascularity, durability, functional expendability. The fascio-cutaneous flap of inner thighs has excellent vascularization because of the presence of branches of the femoral artery (internal and circumflex pudendal), making the flap very reliable in diabetic and patients with ischemic disease [17]. Also, it can be done in short operative time to cover difficult defects. Hallock [18] reported the same flap for scrotal reconstruction following Fournier's gangrene. 
We have seen minor complications such as margin necrosis in two patients of medial thigh flap coverage however, both cases were managed conservatively and the flaps showed good sensation except for transient loss of sensation over anterior part of thigh which regained in the follow-up period. These advantages and disadvantages were comparable to that reported by Ferreira et al. [19] in their review of management of 43 patients of Fournier's gangrene. Donor site complications such as wound dehiscence and infection of the donor site suture line were seen in two patients and one patient respectively. Direct closure was done for wound dehiscence and infection was managed by frequent dressing. These minor complications were comparable to that reported by Ferreira et al. [19].

Anterolateral thigh flap is another option for reconstruction of scrotal defect of Fournier's gangrene. Anterolateral thigh flap is away from the zone of infection in cases of Fournier's gangrene and bring healthy vascularized tissue into the defect. These flaps can cover defect up to $35 \times 25 \mathrm{~cm}$ [20]. Anterolateral thigh flap can be harvested as fascio-cutaneous or musculocutaneous flaps with part of vastus lateralis or as neurocutaneous flap with anterior lateral cutaneous nerve of thigh. Anterolateral thigh flap has some limitations. In obese patients, anterolateral thigh flap would be thick so cannot be used for scrotal reconstruction. Chen et al. [11] reported reconstruction of three scrotal defects with pedicled anterolateral thigh flap cover with good outcome and survival. Spyropoulou et al. [21] used a pedicled ALT flap in nine patients with penoscrotal defect. According to the author, flap appeared bulky in initial postoperative period but oedema subsided during the course of time, leaving a more natural-looking scrotum. In, our study we used ALT flap in seven patients to reconstruct scrotal defect and all flaps survived well with good aesthetic outcome. However, the bulkiness of ALT flap remains its disadvantage.

Groin flap technique is simple and flap advances easily to cover scrotal defects. Groin flap has functional expandability and achieves reasonable aesthetic results. In our cases results were also acceptable. The flap is thin and pliable as compared to other fascio-cutaneous flaps. This flap remains the choice when pliable tissue is required.

The choice of reconstruction technique of scrotal depends upon the site of defect, extent of scrotal involvement, age of patient, comorbidities and surgeon's preference. Both delayed primary closure and STSG are safe, easy and single-stage procedures with shorter hospital stay. However, delayed primary closure is only possible for scrotal defect involving less than $50 \%$ of scrotal surface area and STSG cannot be done when tunica vaginalis is stripped off, although thin skin in STSG resembles a normal scrotum which preserves testicular function. Fascio-cutaneous flaps offer single staged, well-vascularized soft tissue coverage in scrotal defects. Medial thigh flaps can be used for coverage even in diabetic and vasculopathy patients. Anterolateral thigh flaps provide large, hair-bearing cutaneous pedicles that are out of zone of infection and can be harvested as musculocutaneous flaps to obliterate dead space in perineum whereas groin flaps offer thin expandable coverage.

Every modality used to cover scrotal defect has its own pros and cons, so every case needs an individual approach for scrotal reconstruction depending upon patient's condition, patient's requirement and surgeon's expertise to achieve reasonable functional and aesthetic outcome without any major complication and donor site morbidity.

The limitation of our study is a small sample size and lack of standardization, hence it is recommended to conduct randomized controlled trials to evaluate the different methods for soft tissue reconstruction of the scrotum.

\section{Conclusions}

Each case of scrotal defect needs an individualized approach for tailoring the scrotal reconstruction depending upon patient's age, general condition of patient, wound status, comorbidities, patient's requirement and the advantages and disadvantages of the different management modalities will definitely help in decision-making for soft tissue reconstruction of the scrotum under optimal conditions.

\section{Additional Information}

\section{Disclosures}

Human subjects: Consent was obtained or waived by all participants in this study. Faculty of Medicine, Aligarh Muslim University issued approval 642/FM/17. The study has been approved by the institutional ethical committee. Animal subjects: All authors have confirmed that this study did not involve animal subjects or tissue. Conflicts of interest: In compliance with the ICMJE uniform disclosure form, all authors declare the following: Payment/services info: All authors have declared that no financial support was received from any organization for the submitted work. Financial relationships: All authors have declared that they have no financial relationships at present or within the previous three years with any organizations that might have an interest in the submitted work. Other relationships: All authors have declared that there are no other relationships or activities that could appear to have influenced the submitted work. 


\section{Acknowledgements}

We acknowledge Professor Imran Ahmad, our beloved teacher and mentor in our training years who taught us the research aptitude besides plastic surgery and microvascular tissue transfers which has helped us in placement and to continue teaching, learning and research in the field of Plastic Surgery.

\section{References}

1. Klç A, Aksoy Y, Klç A: Fournier's gangrene: etiology, treatment, and complications. Ann Plast Surg. 2008, 54:106-9. 10.1097/00000637-200111000-00009

2. Yoganathan KG, Blackwell AL: Unusual cause of acute scrotal cellulitis in an HIV positive man . Sex Transm Infect. 2006, 82:187-8. 10.1136/sti.2005.017020

3. Yu P, Sanger JR, Matloub HS, Gosain A, Larson D: Anterolateral thigh fasciocutaneous island flaps in perineoscrotal reconstruction. Plast Reconstr Surg. 2002, 109:610-6. 10.1097/00006534-200202000-00030

4. Maguiña P, Palmieri TL, Greenhalgh DG: Split thickness skin grafting for recreation of the scrotum following Fournier's gangrene. Burns. 2003, 29:857-62. 10.1016/j.burns.2003.07.001

5. Ioannovich J, Kepenekidis A, Stamatopoulas K, Matar N: [Use of gracilis musculocutaneous flap in tissue loss caused by Fournier's gangrene. Apropos of 4 cases]. Ann Chir Plast Esthet. 1998, 43:58-63.

6. Coruh A, Akcali Y, Ozcan N, Ekmekcioglu O: Modified pudendal thigh flap for perineoscrotal reconstruction: a case of Leriche syndrome with rapidly progressing Fournier's gangrene. Urology. 2004, 64:1030. 10.1016/j.urology.2004.05.027

7. Core GB, Bite U, Pemberton JH, Petty PM: Sliding V-Y perineal island flaps for large perianal defects . Ann Plast Surg. 1994, 32:328-31. 10.1097/00000637-199403000-00018

8. Zeng A, Xu J, Yan X, You L, Yang H: Pedicled deep inferior epigastric perforator flap: an alternative method to repair groin and scrotal defects. Ann Plast Surg. 2006, 57:285-8. 10.1097/01.sap.0000221466.97653.15

9. Park KR, Kim TG, Lee J, Ha JH, Kim YH: Single-stage reconstruction of extensive defects after Fournier's gangrene with an exposed iliac crest and testes. Arch Plast Surg. 2013, 40:74-6. 10.5999/aps.2013.40.1.74

10. Chen SY, Fu JP, Wang CH, Lee TP, Chen SG: Fournier gangrene: a review of 41 patients and strategies for reconstruction. Ann Plast Surg. 2010, 64:765-9. 10.1097/SAP.0b013e3181ba5485

11. Chen SY, Fu JP, Chen TM, Chen SG: Reconstruction of scrotal and perineal defects in Fournier's gangrene. J Plast Reconstr Aesthet Surg. 2011, 64:528-34. 10.1016/j.bjps.2010.07.018

12. Balakrishnan C: Scrotal avulsion: a new technique of reconstruction by split-skin graft . Br J Plast Surg. 1956, 8:38. 10.1016/S0007-1226(56)80007-6

13. Boukind H, Ezzoubi M, Chafiki N, et al.: La reconstruction scrotale apres cellulite necrosante du perinee et des organes genitaux externes. Ann Urol. 1995, 29:308-12.

14. Hesselfeldt-Nielsen J, Bang-Jensen E, Riegels-Nielsen P: Scrotal reconstruction after Fournier's gangrene. Ann Plast Surg. 1986, 17:310-6. 10.1097/00000637-198610000-00008

15. Parkash S, Gajendran V: Surgical reconstruction of the sequelae of penile and scrotal gangrene: a plea for simplicity. Br J Plast Surg. 1984, 37:354-7. 10.1016/0007-1226(84)90078-X

16. Altchek ED, Hoffman S: Scrotal reconstruction in Fournier syndrome. Ann Plast Surg. 1979, 3:523-8. 10.1097/00000637-197912000-00006

17. Monteiro E, Carvalho P, Costa P, Ferraro A: "Inner thigh lift flap" for Fournier gangrene of the scrotum. Plast Reconstr Surg. 2002, 110:1372-3. 10.1097/00006534-200210000-00041

18. Hallock GG: Scrotal reconstruction following Fournier's gangrene using the medial thigh fasciocutaneous flap. Ann Plast Surg. 1990, 24:86-90. 10.1097/00000637-199001000-00016

19. Ferreira PC, Reis JC, Amarante JM, Silva ÁC, Pinho CJ, Oliveira IC, da Silva PN: Fournier's gangrene: a review of 43 reconstructive cases. Plast Reconstr Surg. 2007, 119:175-84. 10.1097/01.prs.0000244925.80290.57

20. Bhatnager AM, Mohite PN, Suthar M: Fournier's gangrene: a reviewof 110 cases for aetiology, predisposing conditions, microorganisms, and modalities for coverage of necrosed scrotum with bare testes. N Z Med J. 2008, 121:46-56.

21. Spyropoulou GA, Jeng SF, Demiri E, Dionyssopoulos A, Feng KM: Reconstruction of perineoscrotal and vaginal defects with pedicled anterolateral thigh flap. Urology. 2013, 82:461-5.

10.1016/j.urology.2013.04.044 